\title{
A POINT TO BE CONSIDERED IN THE USE OF THE ABDERHALDEN REACTION *
}

\author{
ELLISON L. ROSS, Ph.D., ANd H. DOUGLAS SINGER, M.D., M.R.C.P. \\ KANKAKEE, ILL.
}

Abderhalden has demonstrated that the parenteral introduction into the body of foreign protein or other material results in the appearance in the blood-serum of ferments capable of splitting these foreign substances into bodies which are less disharmonious with the organism. He has shown that these ferments are produced only by the presence in the blood of the corresponding material and that they seem to be specific; that is to say, that they are capable of splitting only the one particular variety of protein, or other substance, the injection of which resulted in their formation.

The dialysis method, by which proteolytic ferments may be detected, recommended by Abderhalden, consists essentially of two parts. First, about $0.5 \mathrm{gm}$. of sterile protein (which must be free from substances which react with ninhydrin) is placed with 1.0 to 1.5 c.c. of the sterile blood-serum under test, free from hemoglobin and blood-cells, in a sterile, tested, and standardized dialyzing thimble. This is then floated in 20 c.c. of sterile water in a sterile vessel and the whole incubated at blood temperature for sixteen hours. Secondly, 10 c.c. of the dialysate is boiled for exactly one minute with 0.2 c.c. of a 1 per cent. solution of ninhydrin. The appearance or non-appearance of a blue color within half an hour is an indication of the presence or absence of amino-acids, polypeptids or peptones (and other substances) and from this it is deduced that lysis of the protein material used in the test has or has not occurred, and hence that the blood-serum does or does not contain a proteolytic ferment for this particular protein. Control tests with the various substances used are obviously necessary.

The discovery of these facts has led to the suggestion that in this reaction we have a means of detecting destruction by injury or disease of any organ within the body; for it is claimed that some of the proteins of which each organ is composed are peculiar to that organ and under conditions of ordinary healthy life do not enter the blood-stream. Destruction of an organ within the body, however produced, leads to the absorption of the specific protein peculiar to it, and although some splitting and lysis probably occurs within the bodies of the migratory

* Submitted for publication, Aug. 6, 1914.

* From the Laboratory of the Illinois State Psychopathic Institute. 
cells which must act as the medium for the transfer of this dead protein to the blood-stream, yet it may be that the substance which finally gains admission to the circulation still retains the essential specific molecular construction of the original tissue protein. This would then give rise to the production of proteolytic ferments in the blood-serum specific for the proteins peculiar to the organ which has been destroyed.

This suggestion has been seized by many workers with the greatest enthusiasm and within the two years which have elapsed since the publication of Abderhalden's 'work an enormous literature has been built up dealing with investigations into pathological conditions of all kinds. Especially true is this in regard to the disorders grouped under the head of psychiatry.

A study of this literature reveals the most contradictory and confusing results, a state of affairs which seems inevitable when the complexity of the series of chemical changes already indicated in the passage of the dead protein from the organ to the blood-stream is considered. When to this is added the rigid and exacting nature of the technic of the final test, the sources of possible error become enormous. To illustrate the situation, reference may be made to the findings in dementia praecox. Fauser claims to have demonstrated that the serum of these patients always contains ferments which will digest the proteins of sex glands and that other types of mental disorder do not show this phenomenon. He is supported by the observations of many others. Yet even among those who more or less conform to this view we find that Kafka, ${ }^{1}$ for instance, reports the digestion of ovary by male serum and of testis by female serum, although he makes no comments on these results. Other observers, on the other hand, not only fail to find such digestion in all cases of dementia praecox, but do find it in other psychoses. Reference may be made, for instance, to the careful work of Simon, ${ }^{2}$ who reports that in 12 per cent. of the cases of dementia praecox examined by him, the serum contained no proteolytic ferment for sex gland, while in 30 per cent. of the other forms of psychosis investigated the serum did possess this property.

So far has enthusiasm been carried that it is quite common to find authors suggest that all observations, whether by themselves or others, which do not conform to the views with which they start are the result of faulty technic, while others even suggest that the clinical diagnosis was incorrect. Even does one find commercial laboratories which make returns "positive or negative for dementia praecox."

1. Kafka: Ztschr. f. d. ges. Neurol. u. Psychiat., 1913, xviii, 348, Cases 11 and 31.

2. Simon, Charles E.: The Abderhalden-Fauser Reaction in Mental Diseases with Special Reference to Dementia Praecox, Jour. Am. Med. Assn., 1914, Ixii, 1701. 
In view of the far-reaching conclusions which are being so confidently drawn and of the contradictory results which have been obtained, it seems that more methodical and careful study of the fundamental problems concerned is eminently desirable.

In the first place, it is difficult to understand why, if tissues like placenta and carcinoma give rise to the appearance in the blood-serum of protective enzymes, the normal tissue cells of the body should not do so likewise. That Abderhalden seems to admit that cell metabolism may have this effect is apparent from his statement in a recent paper ${ }^{3}$ read before the American Medical Association, that "one must abandon the frequently accepted view that the appearance of protective enzymes or of new blood enzymes in general is associated with cell destruction." With this question in view it was decided to make a series of tests on the tissues and serums of healthy dogs and cats. This has led to certain findings which appear of considerable importance.

\section{EXPERIMENTAL, WORK}

The animal was anesthetized with ether. The two jugular veins were dissected out and sterile cannulas were inserted into each end of the cut veins of either side. Blood for serum was drawn into sterile tubes, from a vein or sometimes from the carotid artery. The proximal ends of the veins were connected with a tank containing 0.9 per cent. salt solution. As soon as sufficient blood for serum had been collected, the blood was allowed to flow from the distal ends of the veins. At the same time the salt solution was allowed to enter the blood-stream. This arrangement was allowed to remain till the outcoming fluid was colorless or very slightly pink. Sometimes just before the death of the animal, ammonium oxalate was added to the salt solution. This solution was allowed to run into the body for about ten minutes and then the connections were made with a tank of distilled water so that this water was infused into the body instead of the salt solution.

After the infusion was over the organs were very free from blood. The body was opened and the following organs were removed: brain, thyroid, liver, spleen, pancreas, kidneys, suprarenals and sex glands.

Each of these organs was separately minced and boiled for ten or fifteen minutes with water containing about five drops of acetic acid per liter. The mixture was then filtered. The washing was repeated five to seven times. The tissues were then put into test-tubes which

3. The Present Status of the Investigation of the Protective Enzymes, read before the Section on Obstetrics at the sixty-fifth.annual session of the American Medical Association, Atlantic City, N. J., June. 1914. This has not yet been published, but a copy was kindly furnished by Prof. A. J. Carlson of the University of Chicago. 
were stoppered with cotton plugs. These were then sterilized for half an hour in steam at 5 pounds' pressure.

Blood was also prepared as a substrate. It was washed, boiled and sterilized in exactly the same manner as the tissues.

The blood collected for serum was allowed to stand till the serum separated well from the clot. The serum was removed by decantation or centrifugation and then again centrifuged.

When blood was collected for serum without killing the animal, it was taken with a sterile needle from the saphenous vein.

The parts for the test were assembled as follows: Twenty c.c. of sterile distilled water was placed with a sterile pipet into each cottonplugged sterile test-tube ( 1 inch in diameter and 8 or 10 inches long). The sterile dialyzing thimble was lifted with sterile forceps and held while the sterile substrate and serum, either or both, were introduced. The dialyzing tube was then let gently into the water in the test-tube and the latter again closed. A single complete test consisted of one test with serum alone in the dialyzing-tube, one test with substrate alone and one test with serum and substrate together. The combinations were incubated at $37 \mathrm{C}$. for sixteen hours. After the incubation, 10 c.c. of the dialysate was measured out into a clean large test-tube. To this was added 0.2 c.c. of a 1 per cent. solution of ninhydrin. This solution was boiled strongly for exactly one minute. The color was noted and recorded as negative, questionable, positive, double positive or triple positive, meaning respectively, no color, suspicion of color, just enough blue to be easily seen, an amount of blue about midway between the latter test and the next, and finally, so much blue that it was difficult to see through it against a white background. The result of the complete test was considered positive if the color of the dialysate from the tissue and serum was more intense than the combined color of the other two dialysates. It was considered questionable when the intensity of the color of this dialysate was equal to the other two. The test was negative either when there was no blue color in the tested dialysate of the tissue and serum or when the color was markedly less than the intensity of that of the other two combined. The dialysing thimbles had been tested first for permeability to albumin. They should not allow protein to pass through them. Egg-white was used as substrate and the biuret test for albumin employed in place of the ninhydrin.

The dialysing tubes were next tested for permeability to peptone and standardized in this respect. The regular test was carried out, except that 1 c.c. of 10 per cent. solution of peptone was used in place of the substrate and serum. Those tubes giving a test with ninhydrin of less than a double positive were discarded. Those tubes allowing peptone to pass through sufficiently to give a double positive result with 
TABLE 1.-Results wirh a Strict Abderhalden Technic*

\begin{tabular}{|c|c|c|c|c|c|}
\hline \multirow{2}{*}{ Tissue } & \multirow{2}{*}{$\begin{array}{l}\text { No. of } \\
\text { Tests }\end{array}$} & \multicolumn{2}{|c|}{$\begin{array}{l}\text { Immediately After Boil- } \\
\text { ing for One Minute }\end{array}$} & \multicolumn{2}{|c|}{$\begin{array}{l}\text { After Standing for } \\
\text { Half an Hour }\end{array}$} \\
\hline & & Positive & Doubtful & Positive & Doubtful \\
\hline $\begin{array}{c}\text { Blood (1) } \\
\text { Brain (2) } \\
\text { Kidney } \\
\text { Liver (3) } \\
\text { Pancreas (4) } \\
\text { Spleen (5) } \\
\text { Suprarenal } \\
\text { Sex glands } \\
\text { Thyroid (6) }\end{array}$ & $\begin{array}{l}21 \\
20 \\
22 \\
32 \\
11 \\
15 \\
5 \\
6 \\
9\end{array}$ & $\begin{array}{l}9 \\
4 \\
7 \\
5 \\
1 \\
9 \\
1 \\
3 \\
3\end{array}$ & $\begin{array}{l}1 \\
1 \\
1 \\
0 \\
0 \\
1 \\
0 \\
0 \\
0\end{array}$ & $\begin{array}{r}12 \\
8 \\
9 \\
7 \\
1 \\
7 \\
2 \\
3 \\
4\end{array}$ & $\begin{array}{l}2 \\
3 \\
2 \\
2 \\
2 \\
4 \\
0 \\
1 \\
0\end{array}$ \\
\hline
\end{tabular}

* Included with the foregoing figures are the results of tests in which incubation was prolonged to twenty-four hours. The number of tests and the results with this variation were:

\begin{tabular}{|c|c|c|c|}
\hline Tissue & $\begin{array}{c}\text { No. of } \\
\text { Tests }\end{array}$ & $\begin{array}{c}\text { Immediately } \\
\text { After } \\
\text { Boiling }\end{array}$ & $\begin{array}{c}\text { After } \\
\text { Standing } \\
\text { One-Half } \\
\text { Hour }\end{array}$ \\
\hline $\begin{array}{l}1 \\
2 \\
3 \\
4 \\
5 \\
6\end{array}$ & $\begin{array}{l}2 \\
1 \\
2 \\
2 \\
1 \\
2\end{array}$ & $\begin{array}{c}\text { Positive } \\
\text { Negative } \\
\text { Negative } \\
\text { Negative } \\
\text { Negative } \\
\text { Positive }\end{array}$ & $\begin{array}{c}\text { Positive } \\
\text { Doubtful } \\
\text { Negative } \\
\text { Doubtful } \\
\text { Negative } \\
\text { Positive }\end{array}$ \\
\hline
\end{tabular}

TABle 2.-Results with Strict Abderhalden Technic Expressfid in Percentages

\begin{tabular}{|c|c|c|c|c|}
\hline \multirow{2}{*}{ Tissue } & \multicolumn{2}{|c|}{$\begin{array}{l}\text { Immediately After Boiling } \\
\text { for One Minute }\end{array}$} & \multicolumn{2}{|c|}{$\begin{array}{c}\text { After Standing for Half } \\
\text { an Hour }\end{array}$} \\
\hline & Positive & Negative & Positive & Negative \\
\hline $\begin{array}{l}\text { Blood } \ldots . . . . \\
\text { Brain ........ } \\
\text { Kidney } \ldots . . . \\
\text { Liver ....... } \\
\text { Pancreas ..... } \\
\text { Spleen ...... } \\
\text { Supararena1 .. } \\
\text { Sex Gland.... } \\
\text { Thyroid..... }\end{array}$ & $\begin{array}{r}43 \\
20 \\
32 \\
16 \\
9 \\
60 \\
20 \\
50 \\
33\end{array}$ & $\begin{array}{l}52 \\
75 \\
65 \\
84 \\
91 \\
33 \\
80 \\
50 \\
67\end{array}$ & $\begin{array}{r}57 \\
40 \\
41 \\
22 \\
9 \\
47 \\
40 \\
50 \\
44\end{array}$ & $\begin{array}{l}33 \\
45 \\
50 \\
72 \\
73 \\
27 \\
60 \\
33 \\
56\end{array}$ \\
\hline Average ... & 32 & 66 & 38 & 50 \\
\hline
\end{tabular}


ninhydrin were marked and those giving a triple positive test were also marked. These two classes of tubes were kept separate and no complete test was made in which tubes of the two classes were used together.

The results of 141 tests with a strict Abderhalden technic are given in Tables 1 and 2.

TABle 3.-Results with Incubation for Twenty-Four Hours and Substitution of 0.9 Per Centi. Salt Solution for Distilled Water in the Dialyser

\begin{tabular}{|c|c|c|c|c|c|}
\hline \multirow{2}{*}{ Tissue } & \multirow{2}{*}{$\begin{array}{l}\text { No. of } \\
\text { Tests }\end{array}$} & \multicolumn{2}{|c|}{$\begin{array}{l}\text { Immediately After Boil- } \\
\text { ing for One Minute }\end{array}$} & \multicolumn{2}{|c|}{$\begin{array}{l}\text { After Standing for Half } \\
\text { an Hour }\end{array}$} \\
\hline & & Positive & Doubtful & Positive & Doubtful \\
\hline $\begin{array}{c}\text { Blood } \\
\text { Brain } \\
\text { Kidney } \\
\text { Liver } \\
\text { Pancreas } \\
\text { Spleen } \\
\text { Suprarenal } \\
\text { Sex gland } \\
\text { Thyroid }\end{array}$ & $\begin{array}{r}10 \\
10 \\
9 \\
12 \\
5 \\
11 \\
4 \\
5 \\
6\end{array}$ & $\begin{array}{l}2 \\
6 \\
5 \\
5 \\
2 \\
5 \\
2 \\
4 \\
3\end{array}$ & $\begin{array}{l}0 \\
0 \\
0 \\
0 \\
0 \\
0 \\
1 \\
0 \\
0\end{array}$ & $\begin{array}{l}3 \\
2 \\
4 \\
4 \\
1 \\
4 \\
2 \\
2 \\
2\end{array}$ & $\begin{array}{l}2 \\
2 \\
1 \\
2 \\
1 \\
0 \\
1 \\
2 \\
2\end{array}$ \\
\hline
\end{tabular}

TABle 4.- Results in Table 3 Expressen in Percentages

\begin{tabular}{|c|c|c|c|c|}
\hline \multirow{2}{*}{ Tissue } & \multicolumn{2}{|c|}{$\begin{array}{c}\text { Immediately After Boiling } \\
\text { for One Minute }\end{array}$} & \multicolumn{2}{|c|}{$\begin{array}{c}\text { After Standing for Half } \\
\text { an Hour }\end{array}$} \\
\hline & Positive & Negative & Positive & Negative \\
\hline $\begin{array}{l}\text { Blood } \ldots . . . \\
\text { Brain } \ldots . . . \\
\text { Kidney } \ldots \ldots \\
\text { Liver ....... } \\
\text { Pancreas } \ldots \ldots \\
\text { Spleen } \ldots \ldots \\
\text { Suprarenal } \ldots \\
\text { Sex gland } \ldots \\
\text { Thyroid } \ldots .\end{array}$ & $\begin{array}{l}20 \\
60 \\
56 \\
42 \\
40 \\
45 \\
50 \\
80 \\
50\end{array}$ & $\begin{array}{l}80 \\
40 \\
44 \\
58 \\
60 \\
55 \\
25 \\
20 \\
50\end{array}$ & $\begin{array}{l}30 \\
20 \\
44 \\
33 \\
20 \\
36 \\
50 \\
40 \\
33\end{array}$ & $\begin{array}{l}50 \\
60 \\
44 \\
50 \\
60 \\
64 \\
25 \\
20 \\
33\end{array}$ \\
\hline Average .... & 49 & 48 & 34 & 45 \\
\hline
\end{tabular}

The results given in Tables 1 and 2 prove quite conclusively that the serum of normal animals may frequently contain ferments capable of splitting the protein in a number of the tissues of the body. Similar results were obtained by Lichtenstein and Hage. ${ }^{4}$

4. Lichtenstein, S., and Hage: Nachweis von spez. Fermenten mit Hilfe des Dialysierverfahrens, München. med. Wchnschr., 1914, 1xi, 915. 
If the animals we used were all normal healthy animals, as they all seemed to be, there should have been a more uniform set of results. It seems that the results on any organ tissue should have been all positive or all negative. It was thought that possibly this variation might have been due to the length of time of incubation and to the character of the medium in which the dialyzing tube was floated. Since it takes time for enzymes to do their work, and it also takes time for substances to dialyze, and also since it takes a certain definite amount of protein decomposition products to give a perceptible ninhydrin reaction, the lengthening of the time of incubation to twenty-four hours might increase the number of positive results. Since the activity of the wellstudied ferments of the body is much affected by the medium in which

TABle 5.-Results in Tables 1 and 3 Combined, Expressed in Percentages

\begin{tabular}{|c|c|c|c|c|c|c|c|}
\hline \multirow{2}{*}{ Tissue } & \multirow{2}{*}{ No. Tests } & \multicolumn{3}{|c|}{$\begin{array}{l}\text { Immediately After Boiling } \\
\text { for One Minute }\end{array}$} & \multicolumn{3}{|c|}{$\begin{array}{c}\text { After Standing for Half an } \\
\text { Hour }\end{array}$} \\
\hline & & Positive & Doubtful & Negative & Positive & Doubtful & Negative \\
\hline $\begin{array}{c}\text { Blood } \\
\text { Brain } \\
\text { Kidney } \\
\text { Liver } \\
\text { Pancreas } \\
\text { Spleen } \\
\text { Suprarenal } \\
\text { Sex gland } \\
\text { Thyroid }\end{array}$ & $\begin{array}{r}31 \\
30 \\
31 \\
44 \\
16 \\
26 \\
9 \\
11 \\
15\end{array}$ & $\begin{array}{l}35 \\
33 \\
39 \\
23 \\
19 \\
54 \\
33 \\
64 \\
40\end{array}$ & $\begin{array}{r}4 \\
4 \\
3 \\
0 \\
0 \\
2 \\
11 \\
0 \\
0\end{array}$ & $\begin{array}{l}61 \\
63 \\
58 \\
77 \\
81 \\
44 \\
56 \\
36 \\
60\end{array}$ & $\begin{array}{l}48 \\
33 \\
42 \\
25 \\
12 \\
42 \\
44 \\
45 \\
40\end{array}$ & $\begin{array}{r}13 \\
17 \\
10 \\
9 \\
19 \\
16 \\
12 \\
28 \\
13\end{array}$ & $\begin{array}{l}39 \\
50 \\
48 \\
66 \\
69 \\
42 \\
44 \\
27 \\
47\end{array}$ \\
\hline Average & 213 & 36 & 2 & 62 & 36 & 14 & 50 \\
\hline
\end{tabular}

they act, it was thought important to maintain the original salt concentration of the serum throughout the time of incubation. This would be better accomplished by using a sterile physiological salt solution in place of the distilled water used in the original method. Therefore a number of tests were made modifying the original method in the ways just mentioned; that is, lengthening the time of incubation to twentyfour hours and using 0.9 per cent. salt solution in place of distilled water. The results of seventy-two tests are given in Tables 3 and 4 .

Tables 3 and 4 do not show any marked differences in results from those of Tables 1 and 2. The same lack of uniformity exists. As a whole, about the same percentages of positives and negatives occur as when the original method was used.

Since this alteration in the Abderhalden method did not seem to affect the results, we are justified in combining the figures of Tables 1 , 2,3 and 4 in Table 5 . 
In using the regular method, a number of different serums were used on a series of tissues which were composite mixtures of the same organs of several dogs. Likewise a number of tests were made on the tissues of one dog with the serums of several others. The results are given in Tables 6 and 7 .

The uniformity of these results indicates that the irregularity of those previously reported was not due to differences in the serums. On the contrary, it was probably in the substrate, and most likely in its preparation. The preparation of the tissues had been done with the greatest care, and strictly according to the methods prescribed by Abderhalden. In but two cases out of some hundreds of tests made have the substrates alone given a positive ninhydrin reaction.

TABLE 6.-Tests on a Single Set of Composite Tissues with VARTOUS SERUMS

\begin{tabular}{c|c|c|c|c}
\hline \hline $\begin{array}{c}\text { Donor of } \\
\text { Serum }\end{array}$ & Blood & Spleen & Kidney & Liver \\
\hline $\begin{array}{c}\text { Bird-dog ..... } \\
\text { Bulldog ...... }\end{array}$ & + & - & $\ldots$ & - \\
$\begin{array}{c}\text { Dog 5...... } \\
\text { Terrier B.and }\end{array}$ & + & - & - & - \\
T. ......... & + & $?$ & - & \\
\hline
\end{tabular}

TABle 7.-Tests on Tissues of Dog 5 with Various Serums

\begin{tabular}{c|c|c|c}
\hline $\begin{array}{c}\text { Donor of } \\
\text { Serum }\end{array}$ & Blood & Brain & Spleen \\
\hline Dog $8 \ldots \ldots \ldots$ & - & - & + \\
Dog $4 \ldots \ldots \ldots$ & - & - & + \\
Fox terrier $\ldots$ & - & - & + \\
\hline
\end{tabular}

In reviewing these facts it occurred to us that there might be some substance or substances in the body tissues which is soluble in boiling water containing 5 drops of acetic acid per liter, capable of being broken down by a serum ferment into parts which would give a blue color with ninhydrin; whereas, before the cleavage, ninhydrin would not give the characteristic reaction. If these suppositions were correct, any or all tissues prepared as a substrate might not or might give a positive reaction according as the substrate were or were not washed free of this material.

An attempt was made to separate this hypothetical substance (or substances). The acid washings from the substrates, prepared in the usial manner, were filtered through the best grade of filter-paper. The filtrate was boiled down to a small volume and an equal volume of absolute alcohol was added. A precipitate was formed in every case. This precipitate was centrifuged out and washed about five times by 
centrifugation with equal volumes of water and alcohol. It was then put into a test-tube and set in boiling water for ten or fifteen minutes for the purpose of driving off the alcohol. The tube was then plugged with a cotton stopper and sterilized under steam at about 5 pounds' pressure for twenty minutes. Preparations were made in this manner from brain, kidney, liver, pancreas, spleen, suprarenal, testicle, thyroid and muscle. Emulsions of these preparations were used as substrates in the regular Abderhalden reaction. The results were as shown in Table 8 .

TABLE 8.-Tests Made on Preparations from the Acid Washings of Organs in the Process of Preparing These Organs as Substrates

\begin{tabular}{|c|c|c|c|c|c|}
\hline \multirow[b]{2}{*}{ Tissue } & \multirow[b]{2}{*}{$\begin{array}{l}\text { Source of } \\
\text { Tissue }\end{array}$} & \multirow[b]{2}{*}{$\begin{array}{l}\text { Donor of } \\
\text { Serum }\end{array}$} & \multicolumn{3}{|c|}{ Results } \\
\hline & & & $\begin{array}{l}\text { Ppte. and } \\
\text { Serum }\end{array}$ & $\begin{array}{l}\text { Ppte. } \\
\text { Alone }\end{array}$ & $\begin{array}{l}\text { Serum } \\
\text { Alone }\end{array}$ \\
\hline Brain & Composite & Collie & + & - & - \\
\hline Brain & Composite & Collie & & - & - \\
\hline Kidney & Dog 9 & Bulldog & +++ & - & + \\
\hline Kidney & Dog 9 & Bulldog & +++ & - & + \\
\hline Liver & Dog 9 & ? & & - & - \\
\hline Liver & Dog 9 & ? & + & - & - \\
\hline Pancreas & Dog 9 & Terrier & +++ & - & $+?$ \\
\hline Spleen & Composite & Sheep-dog & + & $-\cdots$ & - \\
\hline Spleen & Composite & Sheep-dog & + & $-\cdots$ & - \\
\hline Suprarenal & Composite & Collie & + & - & - \\
\hline Suprarenal & Composite & Collie & + & -- & - \\
\hline Testis & Composite & Sheep-dog & ++ & -- & - \\
\hline Testis & Composite & Sheep-dog & ++ & - & - \\
\hline Thyroid & Composite & Collie & ++ & - & - \\
\hline Thyroid & Composite & Collie & + & - & - \\
\hline Muscle & Bull dog & Collie & ++ & - & - \\
\hline Muscle & Bull dog & Collie & ++ & - & - \\
\hline
\end{tabular}

Having found that blood treated like other tissue as a substrate gave some positive results, it seemed admissible to prepare blood free from hemoglobin for a further test. The blood was drawn into a flask containing ammonium oxalate. The corpuscles were centrifuged out and were then broken by being allowed to stand in distilled water over night. The mixture was then centrifuged and the residue washed till free from hemoglobin with distilled water. The solid material was placed in a test-tube plugged with cotton and then sterilized as the other substrates. An emulsion of this substance was made in sterile water and used for the Abderhalden reaction. The results were as follows:

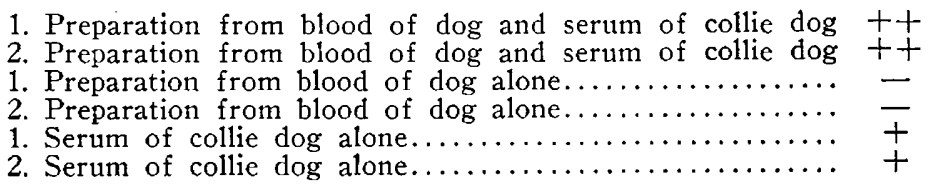


These results show conclusively that there is in each of the tissues with which we worked a substance or a number of substances, which are washed out with acidified water, which do not give a blue color when boiled with ninhydrin, but which are, by normal serum ferments, broken into simpler parts which do give a blue color when boiled with ninhydrin. The question next arose as to whether or not the regular substrates which gave positive results could not have been made negative by further washing and thus freeing the substrate from the materials dealt with above. To demonstrate this point, tests were made on substrates at various stages of washing. The results were as shown in Table 9.

Table 9.-Effect of Progressive Washing of Material Used for Substrates

\begin{tabular}{|c|c|c|c|c|c|}
\hline \multirow[b]{2}{*}{ Tissue } & \multirow{2}{*}{$\begin{array}{c}\text { No. of } \\
\text { Washings }\end{array}$} & \multirow{2}{*}{$\begin{array}{c}\text { Donor of } \\
\text { Serum }\end{array}$} & \multicolumn{3}{|c|}{ Results of Tests } \\
\hline & & & $\begin{array}{l}\text { Tissue and } \\
\text { Serum }\end{array}$ & $\begin{array}{l}\text { Tissue } \\
\text { Alone }\end{array}$ & $\begin{array}{l}\text { Serum } \\
\text { Alone }\end{array}$ \\
\hline Kidney & 1 & Black & +++ & + & - \\
\hline Kidney & 1 & Terrier & $+t+$ & - & - \\
\hline Kidney & 1 & Collie & +++ & - & - \\
\hline Kidney & 2 & Black & $+t$ & $\overline{-}$ & 二 \\
\hline $\begin{array}{l}\text { Kidney } \\
\text { Kidney }\end{array}$ & $\begin{array}{l}2 \\
2\end{array}$ & $\begin{array}{l}\text { Terrier } \\
\text { Collie }\end{array}$ & $+t$ & $\underline{-}$ & E \\
\hline Kidney & 3 & Black & ++ & - & - \\
\hline Kidney & 3 & Terrier & + \pm & - & - \\
\hline $\begin{array}{l}\text { Kidney } \\
\text { Kidney }\end{array}$ & $\begin{array}{l}3 \\
5\end{array}$ & $\begin{array}{l}\text { Collie } \\
\text { Black }\end{array}$ & $\begin{array}{l}+? \\
+\end{array}$ & 二 & 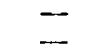 \\
\hline Kidney & 5 & Terrier & $+t$ & - & - \\
\hline Kidney & 5 & Collie & $+?$ & - & - \\
\hline Kidney & 7 & Black & ++ & - & - \\
\hline Kidney & 7 & Terrier & ++ & - & - \\
\hline Kidney & 7 & Collie & + & - & - \\
\hline $\begin{array}{l}\text { Kidney } \\
\text { Kidney }\end{array}$ & $\begin{array}{l}12 \\
12\end{array}$ & Sheep-dog & - & - & - \\
\hline Kidney & 12 & $\begin{array}{l}\text { Black } \\
\text { Collie }\end{array}$ & - & - & - \\
\hline Spleen & 5 to 7 & Terrier & ++ & - & - \\
\hline $\begin{array}{l}\text { Spleen } \\
\text { Spleen }\end{array}$ & $\begin{array}{l}5 \text { to } 7 \\
5 \text { to } 7\end{array}$ & $\begin{array}{l}\text { Collie } \\
\text { Sheep-dog }\end{array}$ & $\stackrel{+}{+}$ & E & E \\
\hline Spleen & 10 to 12 & Sheep-dog & - & - & - \\
\hline Spleen & 10 to 12 & Collie & - & - & - \\
\hline Spleen & 10 to 12 & Black & - & - & - \\
\hline Muscle & 5 to 7 & Terrier & $++t$ & - & - \\
\hline Muscle & 5 to 7 & Collie & + & - & 一 \\
\hline Muscle & 5 to 7 & Sheep-dog & + & - & - \\
\hline Muscle & 10 to 12 & Collie & ++ & - & - \\
\hline Muscle & 13 to 15 & Collie & + & - & $\overline{-}$ \\
\hline Muscle & $\begin{array}{l}13 \text { to } 15 \\
18 \text { to } 20\end{array}$ & $\begin{array}{c}\text { Black } \\
\text { Terrier }\end{array}$ & \pm & $\bar{z}$ & $E$ \\
\hline Muscle & $\begin{array}{l}18 \text { to } 20 \\
18 \text { to } 20\end{array}$ & $\begin{array}{l}\text { Terrier } \\
\text { Sheep-dog }\end{array}$ & 二 & 二 & - \\
\hline Muscle & 18 to 20 & Pointer & 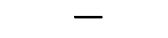 & - & - \\
\hline
\end{tabular}


DISCUSSION AND CONCLUSIONS

It is clear from Tables 1 to 5 that positive Abderhalden tests are frequently obtained with normal serums and substrates prepared from normal blood, brain, kidney, liver, spleen, pancreas, suprarenal, sex gland, thyroid and muscle. From Tables 6 to 9 it is plain that the cause of these positive tests is a material which may be washed out of the substrate, if the washing is continued long enough. Abderhalden's directions for detecting when the substrate is washed enough, however, are not sufficient. The only way to know whether a substrate is fit to use with pathological serums is to have it thoroughly tested with a number of serums from normal persons. If this is not done the results are of small value.

The tests here published show that no definite number of washings can be regarded as sufficient. They must be continued until actual test with normal serums demonstrates the removal of this substance. Abderhalden's directions give no reasons for care in the washing of the substrates, but he does insist ${ }^{3}$ on the need for controls of the substrates used for pathological work by testing with normal serums. Unless this be done the restults, as Abderhalden states, are entirely worthless. The explanation of the need for this care offered here seems to us to explain many of the discordant results which have been published. We might add that this applies especially to the investigation of reactions with the smaller organs, such as the glands of internal secretion where the amount of material available is small and repeated washing means increased waste.

The published reports of work do not state whether the substrates were always the same in any one series nor how much they were washed, and hence must be studied with caution.

The conclusions may be briefly stated as follows:

1. Using the Abderhalden technic with the Abderhalden reaction, the serums of normal animals frequently show evidence of the presence of ferments capable of digesting various tissues of the body.

2. The material causing the positive Abderhalden reactions between normal serum and normal tissue may be precipitated from the washings by the addition of an equal volume of alcohol.

3. The material causing the positive Abderhalden reactions between normal serum and normal tissue may be completely removed from the substrate if the washing is continued long enough. The number of washings required varies with different individuals and different tissues.

4. The only method which will show whether this material is completely extracted from the substrate is to make a number of Abderhalden tests using a number of normal serums. Until this has been done the substrate cannot be considered fit for use with pathological serums. 